\title{
Clinical Audit on Management of Central Nervous System Infections
}

\author{
ELSAYED K. ABD EL-KARIM, M.D.; DUAA M. RAAFAT, M.D. and SAFAA M. ABD EL-ALEEM, M.Sc. \\ The Department of Pediatrics, Faculty of Medicine, Assiut University, Egypt
}

\begin{abstract}
Background: Central Nervous System (CNS) infections cause significant mortality and neurological morbidity throughout the world children.

Patients and Methods: All patients aged beyond neonates admitted to Assiut University Children Hospital (during six month duration) from $1 / 6 / 2017$ to $30 / 11 / 2017$ with any symptoms or signs of meningitis, encephalitis or meningeoencephalitis including fever, convulsions, disturbed conscious level were included in this study to assess how much adopted protocols in management of CNS infections are applied.

Results: Shows that $100 \%$ of patients had lumber puncture, CSF culture was done to $16.4 \%$ of all cases, the first choice of empirical treatment were Ampicillin plus cefotaxime in about $82 \%$ of all cases, vancomycin came after in $19.7 \%$ of them, then ceftriaxone in $18 \%$, nearly all patients were treated with steroid except for one case, $88.5 \%$ were treated with antiviral, mainly all Children ${ }^{<3}$ month with unconfirmed disease treated with cefotaxime + ampicillin for 14 day except for $25 \%$ of them, only $29.8 \%$ of Children $>3$ month with unconfirmed disease treated with ceftriaxone for 10 days.

Conclusion: We need to stick with the international guidelines as a reference standard to avoid miss diagnosis and complications of CNS infections to improve the health services provided in Neurology Unit.
\end{abstract}

Key Words: Meningitis - Encephalitis - Management guidelines - Empiric antibiotics - Steroids - Acyclovair.

\section{Introduction}

MENINGITIS: Is an inflammation of the membranes surrounding the central nervous system: Dura mater, arachnoid mater, and pia mater manifested by CSF pleocytosis [1].

It reflects an inflammation of the arachnoid mater and the CSF in both the Sub arachnoid space and the cerebral ventricles. Meningitis is caused by a myriad of pathogens that can incite different symptoms, often making diagnosis difficult. In younger age groups before speech development,

Correspondence to: Dr. Safaa M. Abd El-Aleem, E-Mail: safaaelkady13@gmail.com frequently few signs and symptoms can be detected. Meningitis, and in particular bacterial meningitis, carries very high morbidity rates (21\%-56\%), which stresses the importance of prompt and correct treatment [2].

The mortality of bacterial meningitis when untreated can approach $100 \%$. There is also a great emphasis on promptly diagnosing and empirically treating meningitis because of the risk of permanent neurologic sequelae, which ranges from $10 \%$ to $30 \%$, according to some sources for bacterial meningitis. Some authors argue that morbidity and mortality vary with geographical location and age and from one pathogen to another $[3,9]$.

It is not surprising that failure to diagnose pediatric meningitis constitutes one of the most common causes of medical malpractice within pediatric emergency medicine [4]. There must always be a high degree of suspicion whenever certain symptoms arise as fever or hypothermia, convulsions, respiratory distress or apnea, bulging fontanelle, jaundice drowsiness, reduced feeding, failure to thrive, unconsciousness, lethargy, highpitched cry, vomiting and Irritability.

Encephalitis: Which is defined as an inflammatory process of the brain parenchyma, shares some of the same etiology and symptoms. Encephalitis represents further disease invasion or progression. The presence or absence of normal brain function distinguishes meningitis from encephalitis [5]. The presence of flaccid paralysis and reduced reflexes is a manifestation of inflammation of the spinal cord, referred to as myelitis.

Men ingoencephalitis: Is a disease in which there are features of both encephalitis and meningitis.

Aseptic meningitis: Is a clinical syndrome in which cultures for routine bacterial pathogens are 
negative and there were no antibiotics given before the Lumbar Puncture (LP). The causes can be infectious and noninfectious, but viruses remain the most common cause. For this reason, aseptic meningitis and viral meningitis are frequently interchangeable terms [6].

\section{Patients and Methods}

All patients aged beyond neonates admitted to Assiut University Children Hospital (during six month duration) from $1 / 6 / 2017$ to $30 / 11 / 2017$ with any symptoms or signs of meningitis, encephalitis or meningeoencephalitis including fever, convulsions, disturbed conscious level were included in this study to assess how much adopted protocols in management of CNS infections are applied.

The following approaches were applied to all cases: Assessment of history, clinical examination, and laboratory investigations that were done to the admitted cases:

- Complete blood count, serum glucose, lumber puncture were done to all patients as a routine.

- Other investigations were done according to the symptoms of the patients.

Indices of the adopted protocols:

\section{1- Empiric antibiotics:}

A- Third generation cephalosporns as cefotaxime $(200-300 \mathrm{mg} / \mathrm{kg} /$ day divided every 6 hours or ceftriaxone $(100 \mathrm{mg} / \mathrm{kg} /$ day divided every 6 hours). hours).

B- Ampicillin $(300 \mathrm{mg} / \mathrm{kg} /$ day divided every 6 hours).

C- Vancomycin $(60 \mathrm{mg} / \mathrm{kg} /$ day divided every 6

2- Steroids (if the child age >3 months) $0.15 \mathrm{mg} / \mathrm{kg}$ to a maximum dose of $10 \mathrm{mg}$, four times dialy for 4 days).

3- Antiviral (acyclovir $60 \mathrm{mg} / \mathrm{kg} /$ day divided every 8 hours).

4- Children $<3$ mon with unconfirmed disease treated with cefotaxime + ampicillin or amoxicillin for at least 14 days.

5- Children > 3mon with unconfirmed treated with IV Ceftriaxone for 10 days disease.

\section{Inclusion criteria:}

- 1 month-16 years.

- Cases of meningitis, encephalitis and meningeoencephalitis.
Exclusion criteria:

- Partially treated meningitis.

- Syndromes.

- Patients known to have previous neurologic insult.

- CNS anomaly.

\section{Results}

A total number of 61 cases, 32 females (52.5\%), 29 males (29\%) aged 2-192 months were admitted to Assiut University Children Hospital with meningitis, encephalitis and meningeoencephalitis during this period.

Our results are shown in the following tables:

Table (1): Distribution of general investigation.

\begin{tabular}{llll}
\hline & & No. & \multicolumn{1}{c}{$\%$} \\
\hline \multirow{2}{*}{ Blood picture: } & Yes & 61 & 100.0 \\
& No & 0 & 0.0 \\
\multirow{2}{*}{ WBCS: } & Normal & 23 & 37.7 \\
& Leucocytosis & 38 & 62.3 \\
Blood culture: & Yes & 0 & 0.0 \\
& No & 61 & 100.0 \\
Blood glucose: $:$ & Yes & 61 & 100.0 \\
& No & 0 & 0.0 \\
\multirow{2}{*}{ Liver enzymes: $:$} & Yes & 2 & 3.3 \\
& No & 59 & 96.7 \\
\hline
\end{tabular}

This table shows that leukocytosis was present in $62.3 \%$ of all cases, and $3.3 \%$ checked for liver enzymes elevation and the result showed elevated enzymes, finally there wasn't any blood culture.

Table (2): Distribution of specific investigation.

\begin{tabular}{llll}
\hline & & No. & $\%$ \\
\hline Lumber puncture: & Yes & 61 & 100.0 \\
& No & 0 & 0.0 \\
Protein in CSF: & Normal & 40 & 65.6 \\
& Increased & 21 & 34.4 \\
& Decreased & 0 & 0.0 \\
Glucose in CSF: & Normal & 47 & 77.0 \\
& Increased & 0 & 0.0 \\
Neutrophils in CSF: $:$ & Yes & 14 & 23.0 \\
& No & 13 & 21.3 \\
Lymphocytes in CSF: $:$ & Yes & 48 & 78.7 \\
& No & 27 & 44.3 \\
Normal CSF: & & 34 & 55.7 \\
CSF culture: & Yes & 18 & 29.5 \\
Result of CSF culture: $:$ & No growth & 10 & 16.4 \\
CSF PCR: & Yes & 51 & 83.6 \\
& No & 0 & 100 \\
& & 61 & 0.0 \\
& & & 100.0 \\
\hline
\end{tabular}


This table shows that $100 \%$ of patients had lumber puncture $29.5 \%$ of them had normal CSF, CSF culture was done to $16.4 \%$ of all cases and all results showed that there was no growth finally it was noticed that there wasn't any CSF PCR.

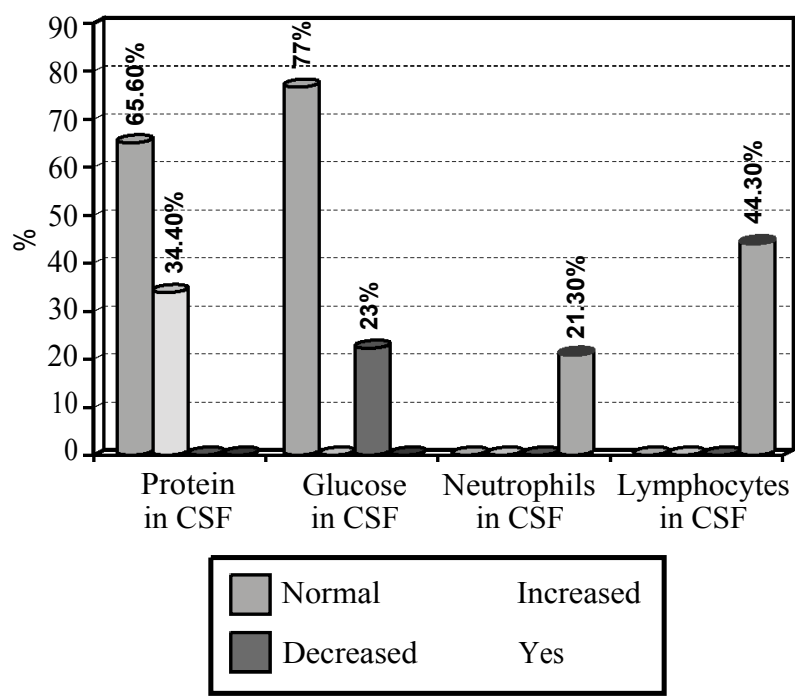

Fig. (1): CSF analysis results.

Table (3): Distribution of empiric treatment.

\begin{tabular}{|c|c|c|c|}
\hline & & No. & $\%$ \\
\hline \multirow[t]{2}{*}{ Empiric antibiotic: } & Yes & 61 & 100.0 \\
\hline & No & 0 & 0.0 \\
\hline \multirow[t]{2}{*}{ Cefotaxime $(200-300 / \mathrm{kg} /$ day): } & Yes & 50 & 82.0 \\
\hline & No & 11 & 18.0 \\
\hline \multirow[t]{2}{*}{ Ceftriaxone $(100 \mathrm{mg} / \mathrm{kg} /$ day): } & Yes & 11 & 18.0 \\
\hline & No & 50 & 82.0 \\
\hline \multirow[t]{2}{*}{ Ampicillin $(300 \mathrm{mg} / \mathrm{kg} /$ day $):$} & Yes & 50 & 82.0 \\
\hline & No & 11 & 18.0 \\
\hline \multirow[t]{2}{*}{ Vancomycin $(60 \mathrm{mg} / \mathrm{kg} /$ day $)$ : } & Yes & 12 & 19.7 \\
\hline & No & 49 & 80.3 \\
\hline Antiviral (acyclovir & Yes & 54 & 88.5 \\
\hline $60 \mathrm{mg} / \mathrm{kg} /$ day): & No & 7 & 11.5 \\
\hline \multirow[t]{2}{*}{ Steroid $(0.15 \mathrm{mg} / \mathrm{kg} /$ day $)$ : } & Yes & 60 & 98.4 \\
\hline & No & 1 & 1.6 \\
\hline Full volume maintenance & Yes & 47 & 77.0 \\
\hline fluids: & No & 14 & 23.0 \\
\hline \multirow[t]{2}{*}{ IV mannitol: } & Yes & 20 & 32.7 \\
\hline & No & 41 & 67.2 \\
\hline \multirow[t]{3}{*}{ Control of convulsion: } & Diazepam & 0 & 0.0 \\
\hline & Phenytoin & 43 & 70.5 \\
\hline & No convulsion & 18 & 29.5 \\
\hline
\end{tabular}

This table shows that the first choice of empirical treatment were Ampicillin plus cefotaxime in about $82 \%$ of all cases, vancomycin came after in $19.7 \%$ of them, then ceftriaxone in $18 \%$, nearly all patients were treated with steroid except for one case, $88.5 \%$ were treated with antiviral, about $77 \%$ of all patients received full volume maintenance fluids only $32.7 \%$ of all cases received one dose of mannitol and all patients who had convulsions were treated with phenytoin.

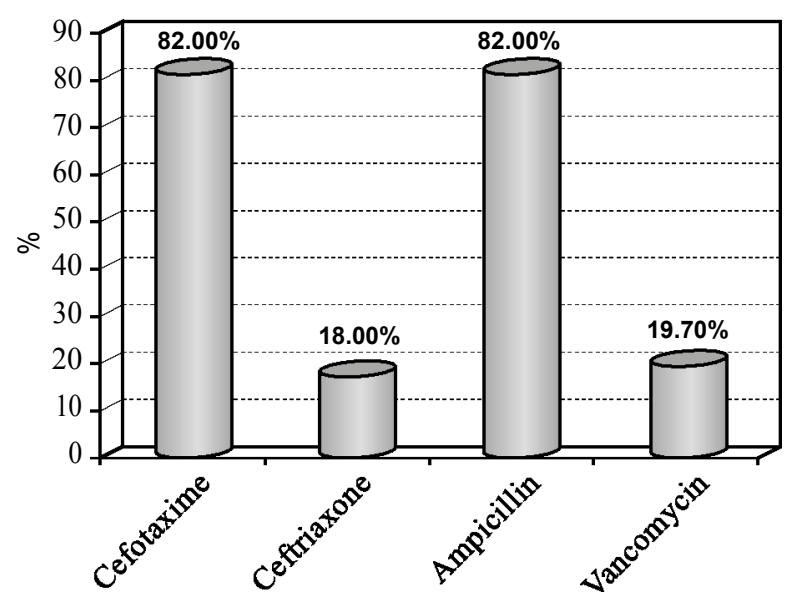

Fig. (2): Empirical antibiotic treatment.

Table (4): Distribution of diagnosis.

\begin{tabular}{lcc}
\hline Diagnosis & No. & $\%$ \\
\hline Meningitis & 10 & 16.4 \\
Encephalitis & 45 & 73.8 \\
Meningoencephalitis & 6 & 9.8 \\
\hline
\end{tabular}

This table shows that the main diagnosis was encephalitis in about $73.8 \%$ of all cases, meningitis came after in about $16.4 \%$, Meningoencephalitis was the least one in about $9.8 \%$.

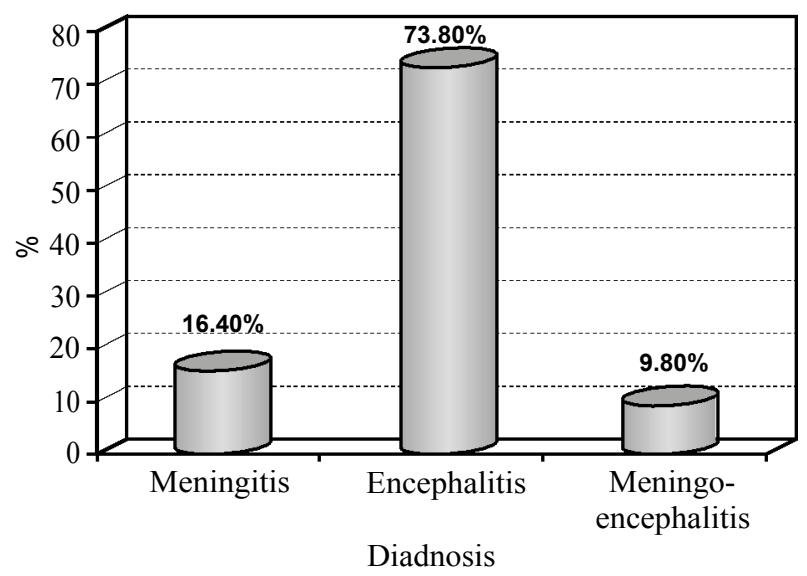

Fig. (3): Diagnosis. 
Table (5): Distribution of treatment.

\begin{tabular}{llcl}
\hline & & No. & $\%$ \\
\hline After culture result stop or & Continue & 10 & 16.4 \\
continue antibiotic: & Stop & 0 & 0.0 \\
Treatment of complication: & Yes & 21 & 34.4 \\
& No & 0 & 0.0 \\
& No complication & 40 & 65.6 \\
Children <3 month with & Yes & 3 & 75 \\
unconfirmed disease & No & 1 & 25 \\
treated with cefotaxime + & & & \\
ampicillin for 14 day: & & & \\
Children > 3 month with & Yes & 17 & 29.8 \\
unconfirmed disease & No & 40 & 70.1 \\
treated with ceftriaxone for 10 & & & \\
days: & & & \\
Acyclovir for 14 days: & Yes & 52 & 85.2 \\
& No & 9 & 14.8 \\
\hline
\end{tabular}

This table shows that antibiotic treatment was continued in all cases because the disease was un confirmed; mainly all children $<3$ month with unconfirmed disease treated with cefotaxime + ampicillin for 14 day except for $25 \%$ of them, only $29.8 \%$ of children $>3$ month with unconfirmed disease treated with ceftriaxone for 10 days, about 85.2\% of all patients were treated with Acyclovir for 14 days and it was also found that all cases followed by complications have been treated in the appropriate way.

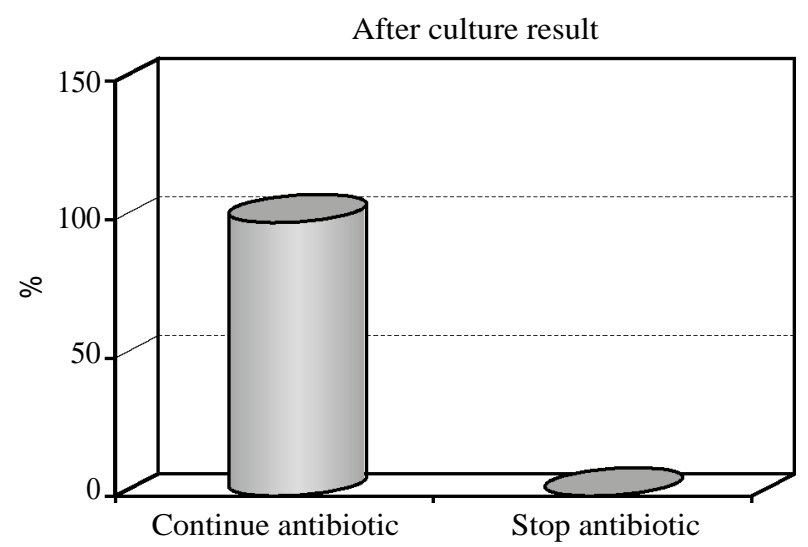

Fig. (4): After culture results stop or continue antibiotic.

Table (6): Distribution of outcome.

\begin{tabular}{lll}
\hline Outcome & No. & $\%$ \\
\hline Good & 46 & 75.4 \\
No response & 4 & 6.6 \\
Icu & 2 & 3.3 \\
Neurological deficit & 7 & 11.5 \\
Death & 2 & 3.3 \\
\hline
\end{tabular}

This table shows that $75.4 \%$ had good outcome, $6.6 \%$ had no response, $11.5 \%$ had Neurological deficit (4 cases developed CP, 2 developed squint and one case developed ataxia), $3.3 \%$ were admitted in the ICU and $3.3 \%$ died.
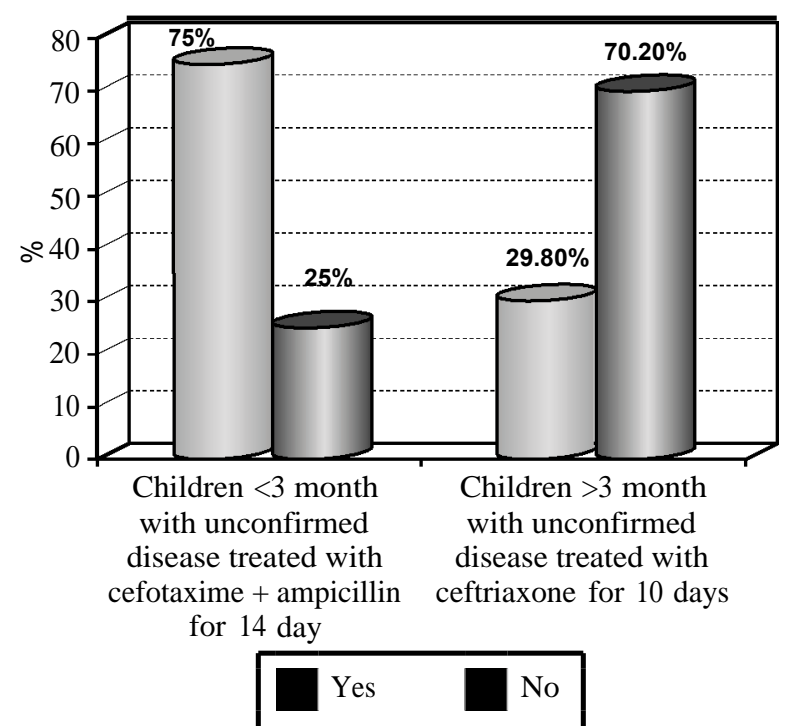

Fig. (5): Treatment of unconfirmed disease.

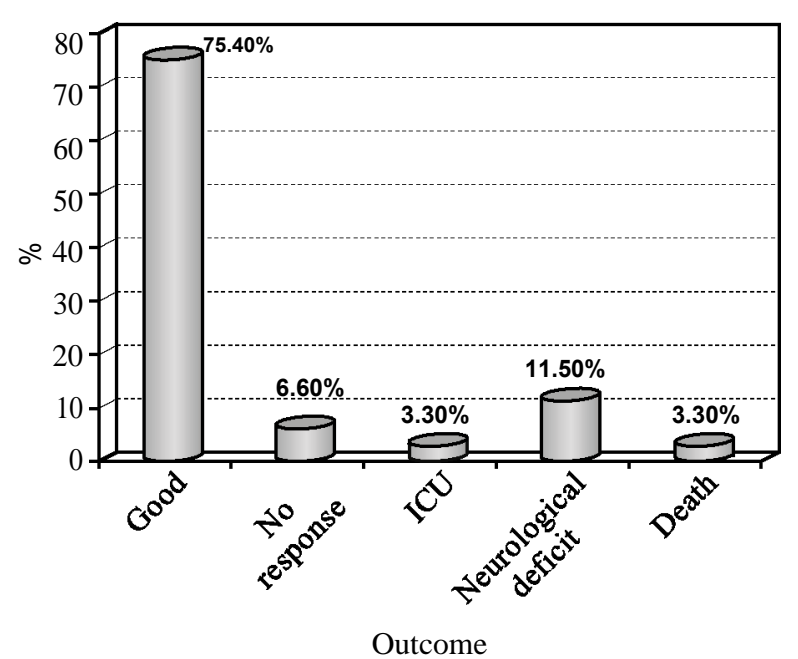

Fig. (6): Outcome.

\section{Discussion}

Infections of the Central Nervous System (CNS) can present with a wide variety of clinical symptoms and signs which are often non-specific, especially in infants and children. Both meningitis and viral encephalitis are neurological emergencies requiring urgent investigation and treatment [7] Especially as distinguishing between the syndromes of meningitis and encephalitis and determining whether the underlying cause is bacterial or viral on clinical grounds which is not straight forward. 
Proven or suspected CNS infections in children are frequent reason for hospital admission and a significant cause of morbidity and mortality [8,9]

In this study it was noticed that investigation following guidelines except for liver function test which was done in 2 cases only, blood culture which was not done at all, CSF culture which was done in 10 cases only, these investigation can easily be done to obtain sure diagnosis, and CSF-PCR was difficult to be done due to it's high cost.

Regarding to diagnosis it was a noticed that $73.8 \%$ were diagnosed as encephalitis, $16.4 \%$ were diagnosed as meningitis and $9.8 \%$ were diagnosed as meningoencephalitis.

Regarding treatment, it was found that there was defect in following guideline in the part of the treatment of unconfirmed disease related to patient's age, patients who were less than 3 months should be treated with ampicillin + cefotaxime and patients more than 3 months should be treated with ceftriaxone.

And finally the outcome of our patients was $75.4 \%$ had good outcome, $6.6 \%$ had no response, $11.5 \%$ had bad outcome (in the form of neurological deficit as cerebral palsy, squint, coma, ataxia), $3.3 \%$ were admitted in the ICU and $3.3 \%$ died.

\section{Conclusion:}

The practitioner should know the typical pathogens, understanding that timely and appropriate use of antimicrobials is essential. Empiric therapy should be administered promptly, once testing is complete, and should include a decision about whether adjunctive steroid therapy is appropriate.

Antimicrobial therapy should be targeted toward the suspected pathogens supportive care and monitoring are imperative, and the practitioner should anticipate and be prepared to treat complications. Although many practitioners are comfortable with the necessary plan of care and monitoring of the pediatric patient who has CNS infections, it is essential that such patients be cared for in a facility that has well-trained ancillary support personnel, including pediatric nursing, critical care, infectious disease, and radiologic staff. Once therapy is complete, all children treated for CNS infections should have follow-up hearing testing.

Evaluation for neurologic sequelae is necessary for all children treated for CNS infection.

\section{Recommendations:}

A- Strict doing liver function test, blood culture and cerebrospinal fluid culture (before starting antibiotics) to obtain sure diagnosis by isolation of the causative organism so that we can describe the appropriate treatment.

B- Improve the facilities for investigations like CSF PCR to verify viral etiology.

C- Strictly follow the guidelines in the diagnosis of CNS infections and strictly follow the guidelines in the starting of treatment.

D- Acyclovir should be given when a neonate is ill appearing, if there is history of maternal genital herpes and/or the presence of mucocutaneous vesicles, if the child presents with seizures or focal neurologic abnormalities, or if hepatic enzyme levels are elevated because of difficult in doing CSF-PCR which confirm viral etiology.

E- Strictly follow the guidelines in continuation and duration of treatment to improve the outcome of the patient.

\section{References}

1- GRANDGIRARD D. and LEIB S.L.: Meningitis in neonates: Bench to bedside. Clin. Perinatol., 37: 655-76, 2010.

2- MACE S.E.: Acute bacterial meningitis. Emerg. Med. Clin. North Am., 26: 281-317, 2008.

3- CURTIS S., STOBART K., VANDERMEER B., et al.: Clinical features suggestive of meningitis in children: A systematic review of prospective data. Pediatrics, 126: 952-60, 2010

4- CARROLL A.E. and BUDDENBAUM J.L.: Malpractice claims involving pediatricians: Epidemiology and etiology. Pediatrics, 120: 10-7, 2007.

5- TUNKEL A.R., GLASER C.A., BLOCH K.C., et al.: The management of encephalitis: Clinical practice guidelines by the Infectious Diseases Society of America. Clin. Infect. Dis., 47: 303-27, 2008.

6- TAPIAINEN T., PREVOTS R., IZURIETA H.S., et al.: Aseptic meningitis: Case definition and guidelines for collection, analysis and presentation of immunization safety data. Vaccine, 25: 5793-802, 2007.

7- RASCHILAS F., WOLFF M., DELATOUR F., CHAFFAUT C., De BROUCKER T., CHEVRET S., LEBON P., CANTON P. and ROZENBERG F.: Outcome of and prognostic factors for herpes simplex encephalitis in adult patients: Results of a multi-centre study. Clin. Inf. Dis., 35 (3): 254-60, 2002.

8- GRANDGIRARD D. and LEIB S.L.: Meningitis in neonates: Bench to bedside. Clin. Perinatol., 37: 655-76, 2010.

9- KIM K.S.: Acute bacterial meningitis in infants and children. Lancet Infect. Dis., 10: 32-42, 2010. 


\section{دراسة تدقيقية للطرق العلاجية لإلتهاب الجهاز العصبى المركزى العاني

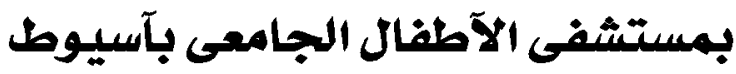

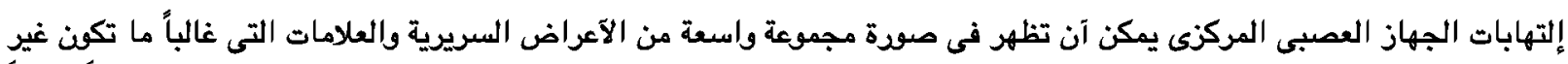

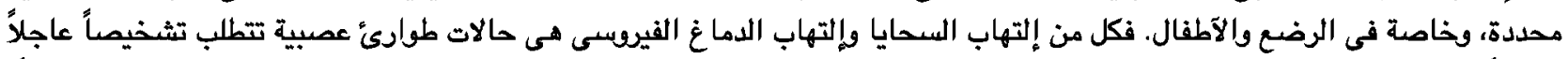

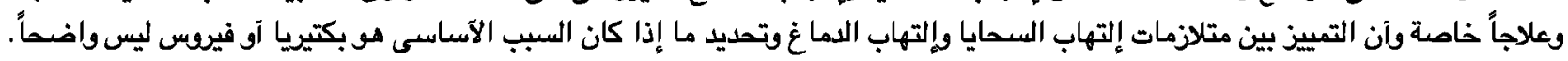
إلتهابات الجهاز العصبى المركزى يمكن الوقاية منها ومعالجتها .والمعرنة الوبائية هى آداة قوية لضمان التشخيص السليم والعلاج السليم.

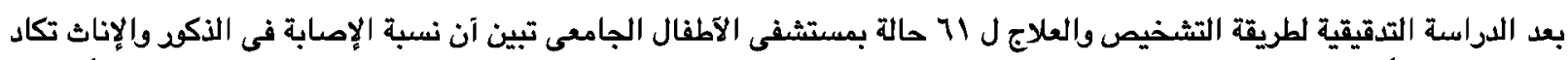

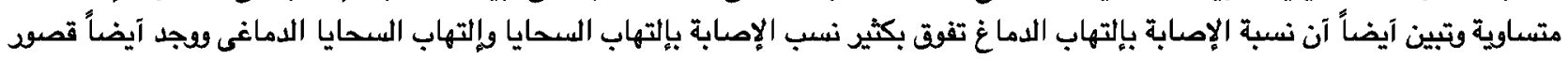

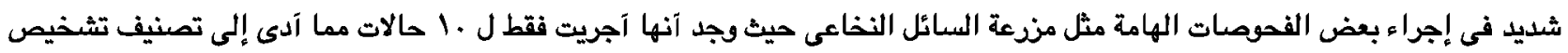

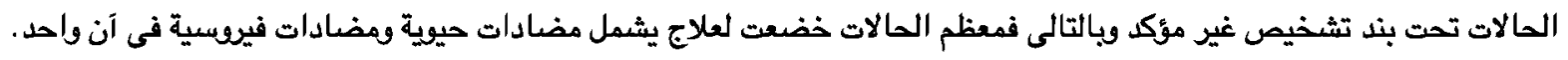

وكانت النتائج النهائية المرضى جيدة حيث وجد آن حوالى ع. \٪٪ من الحالات قد شفيت شفاءاً تاماً.

لتحسين نتائج علاج عدوى الجهاز العصبى المركزى نوصى:

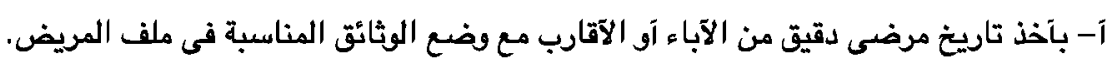

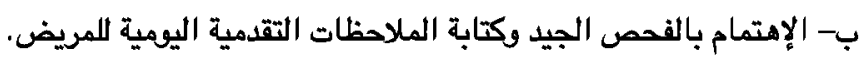
ج- الإهتمام بعمل مزرعة دم بكتيرية ومنرعة بكتيرية للسائل النخاعى (قبل بدء المضادات الحيوية) وعمل وظائف الكبد. د- تحسين وسائل التشخيص وعمل بى سى آر للسائل النخاعى لمعرفة المسبيات الفيروسية. ه- إتباع المبادئ التوجيهية فى تشخيص علدى الجهاز العصبى المركزى وإتباع المبادئ التوجيهية فى بدء العلاج.

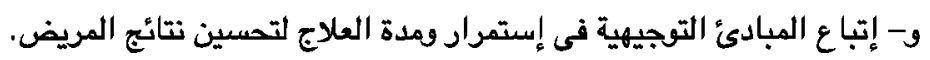

